\title{
GROUND WATER FOR IRRIGATION NEAR GAGE, ELLIS COUNTY, OKLAHOMA.
}

\author{
By David G. Thompson.
}

\section{INTRODUCTION.}

\section{PURPOSE OF INVESTIGATION.}

This report is the result of a field examination to determine the possibility of obtaining water for use in irrigation from deep wells near Gage, Ellis County, Okla. The region is one in which the average precipitation is only about 20 inches a year, an amount barely sufficient for farming. During the two or three years preceding 1918 the precipitation was deficient and the farmers were therefore impelled to consider the possibility of obtaining water for irrigation. In August, 1918, in a well that was being drilled for oil half a mile east of Gage, Okla., a large flow of water, reported to be 40,000 to 50,000 barrels a day, was struck at a depth of 508 feet. In response to a request made to the United States Geological Survey the writer was detailed to investigate the flowing well at Gage and other sources of water in the region which might be available for use in irrigation.

A short time was spent in the vicinity of Gage, and reconnaissance trips were made as far south as Arnett and as far east as Woodward. Data concerning the present sources of water were collected, and logs of deep wells drilled for oil at several places within a radius of 30 miles of Gage were obtained. Several samples of water from different sources were sent to the laboratories of the Geological Survey to be analyzed. Unless otherwise indicated the statements made in this report apply only to the region within a radius of 15 or 20 miles of Gage. The logs of several wells that are farther away from Gage, obtained by $R$. K. Bailey in connection with potash investigations by the Geological Survey, were also studied.

Acknowledgments are due to Messrs. C. H. Holmes, C. J. Minton, and R. M. Sowers, of Gage, to officials of the Home Producers Oil \& Gas Co., of Woodward, and to others for information furnished.

\section{CONCLUSIONS REACHED.}

As the result of a study of the data obtained in the field the conclusion is reached that there is no reasonable prospect of obtaining water for irrigation in this region, except in small areas. Water 
could probably be obtained from deep wells in sufficient quantities for irrigation, but this deeper water is generally so salty that it would probably not only kill the crops but spoil the land for future crops. The water obtained from shallower wells on the uplands is much better and is generally suitable for irrigation, but in many places the depth from which it would have to be pumped would be too great for profitable irrigation. No wells of large diameter have been drilled, and the possible maximum yield of wells on the uplands is not known, but it is believed that the yield would not be sufficient for irrigation. Probably the only part of the region in which good water can be obtained at a reasonable cost is on the flood plain of Wolf Creek, a small area in which water can be found in sufficient quantities at depths of less than 50 feet. The farmers can probably find relief from drought not so much by irrigation as by a careful study of the crops and farming methods best adapted to the climate. The data on which these conclusions are based are given in the following pages.

\section{GEOGRAPHY OF THE REGION.}

The region is reached by the Panhandle line of the Atchison, Topeka \& Santa Fe Railway, which crosses it from northeast to southwest. The Wichita Falls \& Northwestern Railroad extends northwestward along the east side of the region. The principal towns are Shattuck (population 1,365 in 1920), Gage (804), Arnett (404), and Fargo (258). ${ }^{1}$ (See fig. 5.) Arnett, the county seat of Ellis County, is not on the railroad but can be reached by automobile from Gage. Woodward (population 3,849), the county seat of Woodward County, lies 24 miles northeast of Gage, outside of the region considered.

The region is primarily agricultural; it contains no factories or mines. The land in Ellis County and in the western tier of townships of Woodward County generally is better suited to agriculture than that in the region farther east, where the soil is derived from the Permian "Red Beds," which in many places contain so much gypsum or salt that they form soil unfit for raising crops. The erosion of the "Red Beds" has in some places resulted in badlands too rough to be farmed. Along Wolf Creek there are sand hills, which are generally covered with wild grasses and unfit for agriculture. The soils in the region west of that in which the "Red Beds" are exposed are derived from Tertiary sands and sandy clays and are fairly fertile. It is reported that no public lands remain unsold in Ellis County, and probably about half the area of the county is under cultivation.

${ }^{1}$ Fourteenth Censis Bull. Oklahoma, 1921. 
The principal crops raised in the region are wheat, Kafir corn, Milo maize, feterita, cane, and broom corn. Sudan grass has yielded good crops but so far has not been planted extensively. Broom corn

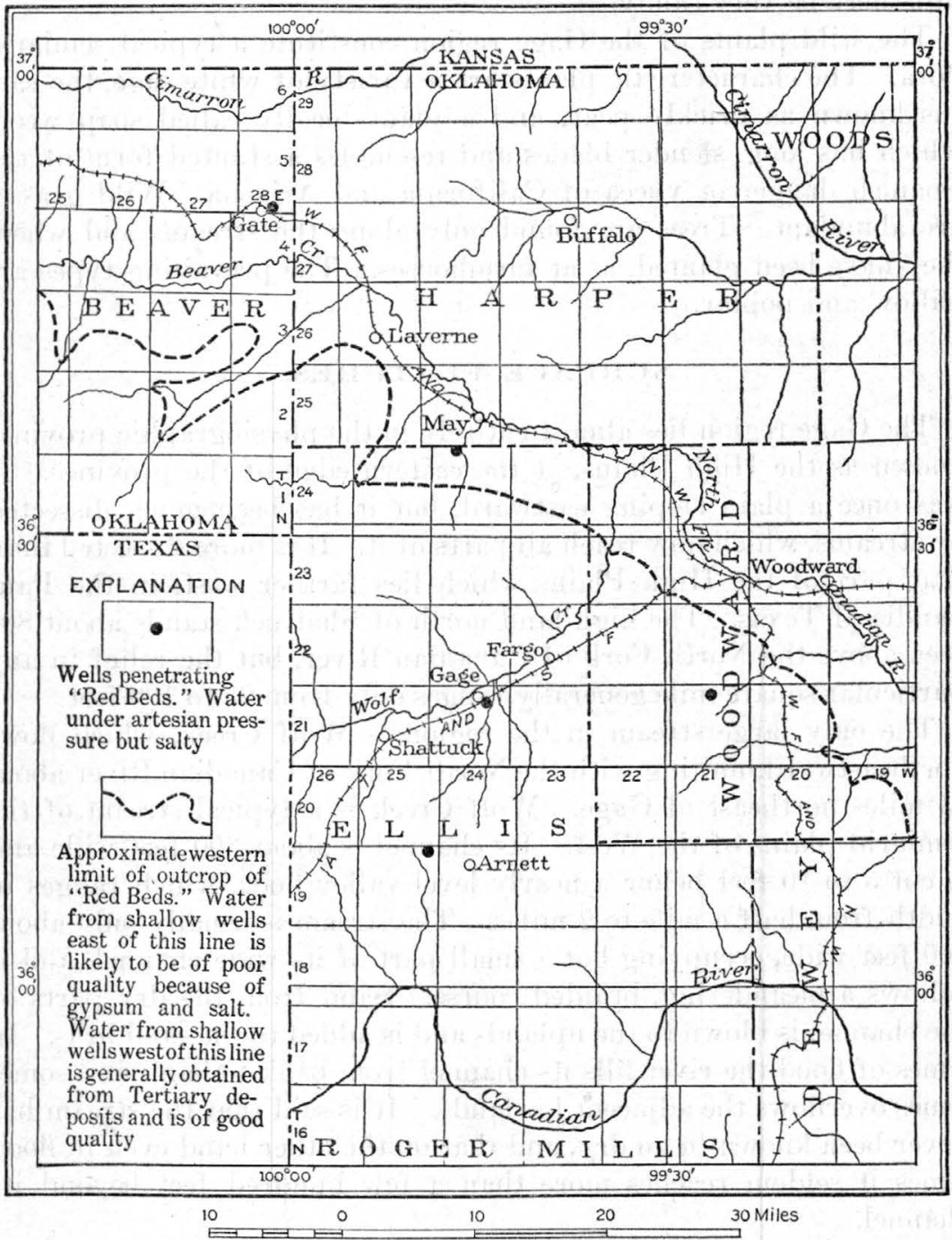

Ficuke 5.-Map of northwestern Oklahoma showing location of certain wells near Gage. Only the wells referred to in this report are shown.

is one of the most valuable crops; as many as 300 carloads of it are reported to have been shipped from Gage in a single season.

- As the rainfall is small only a little corn is raised, and for the same reason very little fruit is grown. Lands that are too hilly or rocky to be cultivated are used for the pasturage of cattle and sheep. 
Roads have been laid out on nearly all the section lines, and those in the area underlain by Tertiary rocks are usually in good condition. The roads in the "Red Beds" area are rougher, and those in the sand hills may be very sandy.

The wild plants of the Gage region constitute a typical semiarid flora. The characteristic plants are a variety of white sage, the cactus known as prickly pear, and a plant locally called soap weed, which has long, slender blades and resembles a stunted form of the Spanish dagger or yucca of California and Arizona. Wild grasses are abundant. Trees are found only along the streams and where they have been planted, as at farmhouses. The prevailing types are willow and poplar.

\section{SURFACE FEATURES.}

The Gage region lies almost entirely in the physiographic province known as the High Plains, at the eastern edge of the province. It was once a plain sloping eastward, but it has been much dissected by streams, which now reach all parts of it. It is more dissected than that part of the High Plains which lies farther west, in the Panhandle of Texas. The high land north of Shattuck stands about 800 feea above the North Fork of Canadian River, but the relief in any particular square mile generally ranges only from 25 to 100 feet.

The only large stream in the region is Wolf Creek, which flows northeastward, uniting with the North Fork of Canadian River about 25 miles northeast of Gage. Wolf Creek is a typical stream of the semiarid plains of the West. Its channel is about 300 feet wide and is cut 5 to 10 feet below a nearly level valley floor, which ranges in width from half a mile to 2 miles. The stream is usually only about 100 feet wide, occupying but a small part of its wide channel, and it follows a meandering, braided course. Sand from the dry parts of the channel is blown to the uplands and is added to the sand hills. In times of flood the river fills its channel from bank to bank and sometimes overflows the adjacent lowlands. It is said that the stream has never been known to go dry, and that on the other hand even in flood times it seldom reaches more than a few hundred feet beyond its channel.

Several minor streams enter Wolf Creek; the largest is Twenty-five Mile Creek, which heads about 14 miles northwest of Gage. After heavy rains these streams rise rapidly and do considerable damage to roads and bridges. Most of them cease flowing in dry seasons, but water is said to stand in pools in their beds, even in the driest years. In the lower parts of their courses they are bordered by flats a few hundred feet wide, but for most of their length they have no flood 
plains. The valleys of these minor streams are cut 10 to 50 feet below the adjacent uplands, but the slopes are nowhere very steep.

The floor of the valley of Wolf Creek is underlain by alluvium. At some time in the past Wolf Creek excavated its valley deeper than it is at present and later partly refilled it with sand and gravel and formed an extensive flood plain. The creek is now flowing in a channel which it has cut a few feet into the alluvium. In parts of the valley the alluvium is covered with wind-blown sand.

The upland reaches elevations of 300 feet or more above the valley floor of Wolf Creek. Some parts of it are nearly level, but other parts, particularly those near the minor streams, have a slope of 50 to 100 feet to the mile. Most of the upland is underlain by sand or clay, but in some places hard rocks crop out in prominent ledges that cap hills.

\section{GEOLOGY.}

Permian, Tertiary, and Quaternary deposits are exposed at the surface in the Gage region, and possibly also some Cretaceous rocks. ${ }^{2}$

\section{PERMIAN DEPOSITS-THE “ RED BEDS."}

The oldest rocks exposed in the region are the "Red Beds," of Permian age. They are at the surface in the eastern part of the region, but they disappear under younger, light-colored deposits about 3 miles west of Woodward. The "Red Beds" have been divided into several formations. Those at the surface near Woodward belong to the Woodward formation, which consists essentially of shale, sandstone, and dolomite and is characterized by the absence of gypsum. In other parts of the "Red Beds" area the Woodward formation is overlain by the Greer formation, which consists of red clay, shale, and sandstone, interbedded with layers of gypsum and dolomite. The presence of gypsum is especially characteristic of the formation, and in many places it contains salt. The Greer formation crops out in the southeastern part of Ellis County, and it may occur above the Woodward formation in the region west of Woodward, where the "Red Beds" are covered by Tertiary beds. The Woodward formation overlies the Blaine formation, which, like the Greer, contains thick beds of gypsum. Gypsum-bearing beds were penetrated in the deep well at Gage and in at least two other deep wells drilled for oil in the region. It is not possible to correlate

\footnotetext{
2 Practically no detailed work has been done on the geology of the Gage region, and the writer had opportunity to make only hasty observations. The statements made concerning the geology are based mainly on the following reports :

Gould, C. N., Geology and water resources of Oklahoma: U. S. Geol. Survey WaterSupply Paper 148, pp. 22-84, 1905.

Snider, L. C., Geography of Oklahoma : Oklahoma Geol. Survey Bull. 27, pp. 43-56, 1917. Aurin, Fritz, Geology of the Red Beds of Oklahoma: Oklahoma Geol. Survey Bull. 30, 1917.
} 
definitely the beds penetrated in these wells, partly because the logs of the wells are not strictly reliable and partly because the "Red Beds" vary considerably in character within short distances. It is believed, however, that the gypsum-bearing beds penetrated in the wells belong to the Blaine formation, as they lie at depths of about 450 feet, above which are considerable thicknesses of "Red Beds" that apparently do not contain gypsum and are probably part of the Woodward formation. In the Gage well "gyp" rock was reported at 144 feet. The writer found that ordinary sandstone or sandy shale is often called "gyp" in the Gage region and that in some places gypsum is not recognized, so that the statement as to the Gage well may be without particular significance. If, however, gypsum was penetrated at 144 feet it probably belongs to the lower part of the Greer formation.

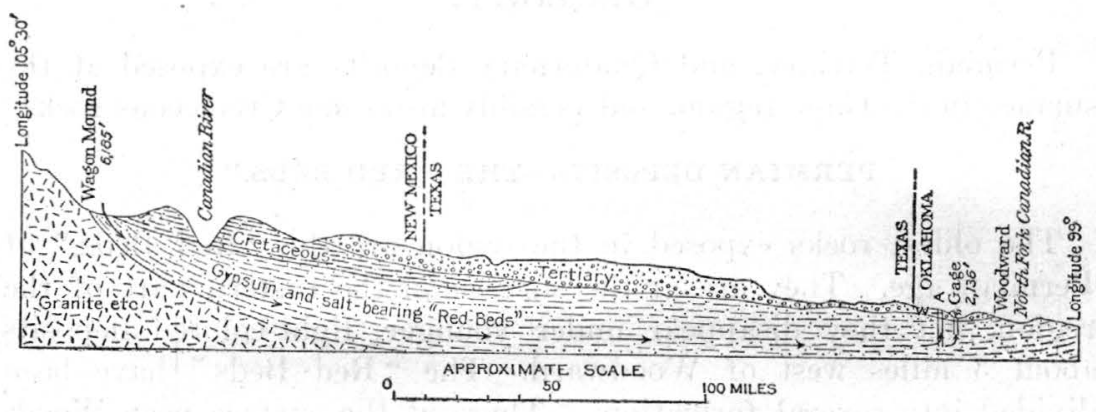

F'IGURE 6.-Diagrammatic cross section between Gage, Okla., and Wagon Mound, N. Mex. (after Gould), showing probable structure of "Red Beds," source of water, and cause of artesian flow at Gage. Arrows show movement of water. Well at Gage will flow because of pressure of water from the west. Well at A, on higher ground, may not flow, but water will rise to level W, which is sligintly above surface elevation at Gage. There may be local folds that are not shown. Vertical scale greatly exaggerated.

The gypsum and salt that are abundant in the "Red Beds" are readily soluble, and water that has passed over or through such beds is usually unfit for any use, owing to its high content of calcium sulphate. In the "Red Beds" area, therefore, the water obtained in wells is usually so highly mineralized that it can not be used, and the inhabitants must depend on cisterns for a supply for domestic and other purposes. In areas where the rocks from which the water is obtained are dolomite, sandstone, and shale, without gypsum, as in the region underlain by the Woodward formation, the water is usually of better quality.

The "Red Beds" dip gently south of west where they are exposed east of Woodward and have a slight dip in the same direction where they disappear under the Tertiary deposits west of Woodward. Logs of deep wells west of Woodward do not afford sufficient data to make it possible to determine accurately the structure of the "Red Beds" where they are overlain by later deposits. "Red Beds" similar to 
those in Oklahoma are found in New Mexico, where they dip to the east at slight angles. These beds in New Mexico in part belong to the same series (Permian) as the beds in Oklahoma and are in part younger (Triassic). The fact that the "Red Beds" dip in a westerly direction where they disappear under the Tertiary deposits near Woodward and in an easterly direction in New Mexico suggests that in the intervening area the beds form a large syncline or trough.

Figure 6 is a generalized cross section showing these conditions. It is probable that the regular eastward dip of the beds is interrupted in places by local folds. Such a condition is shown in figure 7 , which represents on a larger scale a possible interpretation of the structure of the eastern part of the region shown in figure 6 . It should be borne in mind that the two sections are generalized and in part theoretical and should not be understood to indicate the presence or absence of oil.

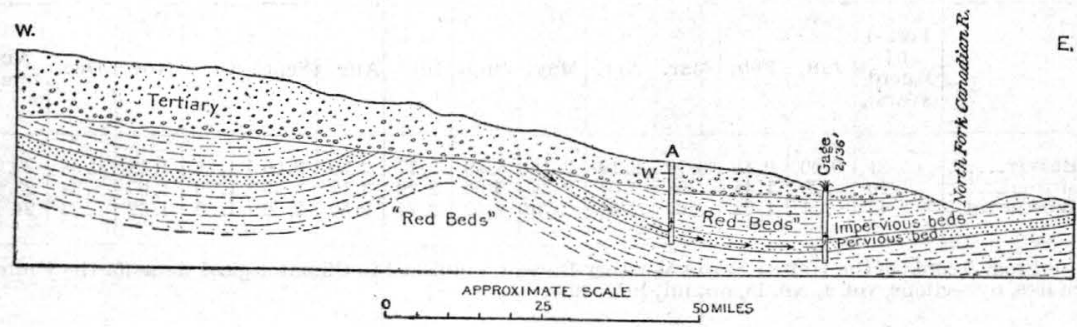

Figure 7.-Theoretical cross section showing possible structure near Gage, Okla., and source of water in flowing well at Gage. Arrows indicate movement of water in the "Red Beds," which the water enters by percolation from the Tertiary deposits. Well at Gage will flow because of pressure from the west. Well at A, on higher ground, will not flow, but water will rise to leved $W$, which is slightly above surface elevation at Gage. Vertical scale exaggerated.

\section{TERTIARY DEPOSITS.}

West and southwest of Woodward the "Red Beds" are overlain by deposits of sandstone and shale, usually light gray, that belong to the Tertiary system. Most of these deposits are rather soft and incoherent, but they include hard layers. The beds in general have an eastward dip, but it is so slight that it is not noticeable unless careful measurements are made. Tertiary deposits may also occur on the uplands on the northeast side of the North Fork of Canadian River, but the geology of that region has not been carefully studied. No detailed investigations of the Tertiary deposits have been made, and their exact position in the geologic column is not known.

\section{QUATERNARY DEPOSITS.}

The Quaternary deposits consist of gravelly and sandy alluvium along the larger streams and of dune sand blown principally from the alluvium by the strong winds that occur in the region. 


\section{CLIM ATE.}

\section{PRECIPITATION.}

The Gage region lies in the semiarid belt of the United Statesthat is, the belt in which the average annual precipitation is between 20 and 30 inches. No records of the precipitation at Gage for any extended period are available, but records have been kept for 10 years or more at several points within 60 miles of that town. The average annual precipitation at three of these places is given in the following table. Beaver is about 60 miles northwest of Gage, Mutual is about 35 miles southeast of Gage, and Woodward is about 20 miles east of Gage.

Average monthly and annual precipitation at certain points in northwestern Oklahoma. ${ }^{a}$

\begin{tabular}{|c|c|c|c|c|c|c|c|c|c|c|c|c|c|c|}
\hline & $\begin{array}{c}\text { Period } \\
\text { of } \\
\text { record } \\
\text { (years). }\end{array}$ & Jan. & Feb. & Mar. & Apr. & May. & June. & July. & Aug. & Sept. & Oct. & Nov. & Dec. & $\underset{\text { nual. }}{\text { An- }}$ \\
\hline $\begin{array}{l}\text { Beaver....... } \\
\text { Mutual...... } \\
\text { Woodward. }\end{array}$ & $\begin{array}{l}21 \\
10 \\
15\end{array}$ & $\begin{array}{r}0.60 \\
.29 \\
.51\end{array}$ & $\begin{array}{l}0.41 \\
1.44 \\
1.22\end{array}$ & $\begin{array}{r}0.70 \\
.68 \\
.67\end{array}$ & $\begin{array}{l}2.19 \\
2.07 \\
2.01\end{array}$ & $\begin{array}{l}2.71 \\
2.38 \\
2.70\end{array}$ & $\begin{array}{l}3.19 \\
3.00 \\
2.52\end{array}$ & $\begin{array}{l}2.77 \\
2.29 \\
2.74\end{array}$ & $\begin{array}{l}2.36 \\
3.12 \\
2.50\end{array}$ & $\begin{array}{l}2.06 \\
3.45 \\
2.56\end{array}$ & $\begin{array}{l}1.28 \\
1.70 \\
1.50\end{array}$ & $\begin{array}{l}1.19 \\
1.65 \\
1.52\end{array}$ & $\begin{array}{r}0.58 \\
1.88 \\
.73\end{array}$ & $\begin{array}{l}20.04 \\
23.95 \\
21.18\end{array}$ \\
\hline
\end{tabular}

a From records of the United States Weather Bureau, published in Climatological data for the United States, by sections, vol. 4, No. 13, pp. 101, 102. 1917.

The table shows that the average annual precipitation in the region is less than 25 inches, and that for the three points at which records have been kept it is least at the westernmost point and greatest at the easternmost point. The average annual precipitation at Gage is probably not far from 21 inches.

The table shows that most of the precipitation occurs in the six warm months from April to September, inclusive. At Beaver and Woodward the amount for these months is more than 70 per cent of the total, and at Mutual the percentage is only a little less. Some of the precipitation in the winter is in the form of snow, but the snow seldom remains long on the ground.

In 1918 there was a dry period during the summer. The United States Weather Bureau record for Woodward for the period from April to September, inclusive, showed a deficiency from the normal of 2.17 inches, all of which occurred during June, July, August, and September. The total deficiency for these four summer months was 4.46 inches, but for April and May there was a surplus of 2.29 inches. Heavy rains occurred in the last three months of the year, with the result that the precipitation for the entire year was 25.38 inches, a surplus of 4.20 inches over the normal 


\section{TEMPERATURE.}

The mean annual temperature of the Gage region is probably between $55^{\circ}$ and $60^{\circ} \mathrm{F}$., but there is usually a considerable annual range. A study of the United States Weather Bureau records for a number of years at Woodward, the station nearest to Gage, shows ranges from at least $18^{\circ}$ below zero to $110^{\circ}$ above.

The daily temperature range is often considerable. This is an important factor in agriculture, especially in the winter, when it is not uncommon for the temperature to rise above $60^{\circ}$ during the day and to fall to several degrees below the freezing point the following night. Ranges of more than $50^{\circ}$ have been reported frequently during January and February. On February 3, 1917, at Woodward, the temperature ranged from zero to $67^{\circ}$, and on February 25 of the same year from $21^{\circ}$ to $84^{\circ}$. These variations in temperature are detrimental to the raising of winter wheat, especially when the ground is not covered with a blanket of snow. Much of the wheat is often killed in the winter, requiring a second seeding, with the result that it develops late and the planting of the following summer crop is therefore somewhat delayed. Frost may generally be expected from the latter part of October to the first part of April. High summer temperatures are common, the thermometer often rising above $90^{\circ}$, and temperatures of $100^{\circ}$ to $110^{\circ}$ are not rare. The daily range is generally somewhat less in the summer than in the winter.

WINDS.

Strong wind is a characteristic feature of the weather in the Gage region, blowing for many days at a time. Practically all the wells in the region are pumped by windmills. The wind often is warm and exerts a considerable drying influence on the soil, doing considerable damage to crops.

\section{SOURCES OF WATER SUPPLY.}

The water supply of the Gage region is at present nearly all obtained from dug or drilled wells a few feet to about 200 feet deep. At a few places water is obtained from springs. In the following pages the present sources of supply, and others that might be used for irrigation are considered.

\section{ALLUVIUM OF STREAM VALLEYS.}

The alluvium underlying the valley floors of the larger streams is unconsolidated, and as it is composed principally of sand and gravel it is very porous and can hold a large quantity of water. Much of the water that runs off from the hillsides adjoining the valley floors 
percolates into the porous beds, and some water is added to them from the streams that flow across them. If water is pumped from such deposits there is opportunity for the supply to be replenished. These deposits will therefore yield large amounts of water year after year. Water is usually obtained in them at slight depths and stands near the surface in wells. Definite information was procured concerning only two valley wells, both of which have good yields.

The public supply for Gage is obtained from a gang of six driven pipes about one-third of a mile south of Wolf Creek. These pipes are in a pit 10 feet in diameter, dug 10 feet deep, and are driven to a total depth of 39 feet from the surface. The 10-foot pit was dug through sand and clay. Water was encountered at 11 feet, and below this was clay to 33 feet. This clay was saturated, but it was so fine that it would not yield water rapidly. A good supply of water was obtained in sand between 33 and 39 feet, and the bottom of the water-bearing bed apparently was not reached. Each pipe is 2 inches in diameter and is equipped with a 60 -gage screen 6 feet long. The well is pumped with a centrifugal pump, and the six pipes together have yielded as much as 200 gallons a minute, which is the capacity of the pump. They are usually pumped at only 135 gallons a minute. When the well is not being pumped the water stands 11 feet from the surface, but when it is pumped at the rate of 135 gallons a minute the water level is lowered 13 feet. An assay of a sample of water from. this well shows it to be of fair quality for domestic use and good for irrigation but poor for use in boilers. (See No. 1, p. 50.)

At Fargo the Atchison, Topeka \& Santa Fe Railway Co. has a dug well 20 feet in diameter and about 35 feet deep. This well is fully a mile from Wolf Creek, at a point where the flood plain of the creek is widened by Boggy Creek, which enters it from the south. The depth to the water level is about 23 feet. No log of the well is available. The well yields 10,000 gallons an hour (about 165 gallons a minute). When it is pumped at this rate the water level is lowered 10 feet in 10 to 12 hours. No analysis of the water is available, but aside from the fact that it is hard it is said to be of good quality.

It is believed that water can be obtained from wells on the valley floor of Wolf Creek in sufficient quantity and of good enough quality for irrigation. Along tributaries of Wolf Creek, however, the alluvium is not extensive, and good supplies adequate for irrigation probably can not be obtained except near their junction with the main stream.

\section{TERTIARY DEPOSITS.}

In the vicinity of Gage all the wells on the uplands derive their supply from Tertiary deposits. Practically all these wells are 
drilled, because of the depth to which it is sometimes necessary to go to obtain water. The wells range in depth from less than 50 feet to 200 feet or more, but most of them are probably between 50 and 150 feet deep. The depth to the water level in most of the wells is between 25 and 100 feet. The depth to water varies from place to place but in general is greatest on the highest land. When water is struck it does not rise more than a foot or two in the well. There are no indications of artesian conditions.

Water is usually obtained in layers of sand or gravel, in places more or less consolidated, overlain and underlain by clayey or shaly beds. The clayey beds may also contain water, but they are too fine grained to furnish adequate supplies to wells. The driller usually does not stop when he first strikes water but drills through the underlying clay and penetrates the next water-bearing bed, the supply of which is less subject to contamination and less likely to be greatly diminished in times of drought. It is probable, however, that here, as in the Tertiary deposits in other parts of Oklahoma, the waterbearing beds are not continuous for great distances but form irregular lenses or stringers. For this reason the depth to the waterbearing sand or gravel may differ considerably in places only a mile or two apart.

No adequate information is available in regard to the maximum quantity of water that might be obtained from wells on the uplands. Most of the wells are used only for domestic purposes and for watering a few head of stock, and no attempt has been made to obtain large supplies. Practically all the wells are pumped by windmills or hand pumps, and it is difficult to get a good test. Furthermore, most of the wells are only 2 inches in diameter. The maximum yield reported in any well on the uplands was estimated at 7 to 10 gallons a minute from a 3 -inch pipe. This well is on the place of L. Zahn, in the NE. $\frac{1}{4}$ sec. 12, T. 21 N., R. 23 W., about 35 feet above a creek. The depth of the well is 55 feet, and the depth to the water level is 27 feet. The only well equipped with a gasoline engine for which data were obtained is one at the county courthouse at Arnett. This well is 130 feet deep, and the water level is approximately 90 feet below the surface. The well is 6 inches in diameter, but the pump pipe is only $1 \frac{1}{4}$ inches in diameter. This well yielded only 5 gallons a minute in a test. It is reported that when the well is pumped the water level is lowered about 20 feet. It is believed that most of the wells with 2-inch pipes will yield not more than 5 to 10 gallons a minute. If the wells were of larger diameter they might yield more freely, but with heavy pumping the supply would probably be seriously depleted. 
Springs occur at a number of places in the Gage region, and their water comes from Tertiary deposits. None of these were visited, however, and no definite information in regard to them is available. Most of them occur on streams, where valleys have been cut across a water-bearing stratum. At some of them the owners have built dams and impounded the water; at others the water is allowed to run freely.

The water from the Tertiary deposits is generally of good quality. (See assay of a typical sample (No. 3) on p. 50.) In the eastern part of the Gage region, where the Tertiary deposits are comparatively thin and are underlain by the "Red Beds," if a well is drilled too deep it may penetrate the "Red Beds." Water from the "Red Beds" is likely to be of somewhat poorer quality than that from the Tertiary deposits.

\section{PERMIAN “ RED BEDS."}

Except near the eastern edge of the region, where the Tertiary deposits are thin, no wells that are used for water supply penetrate the "Red Beds." They have been reached, however, in several wells drilled for oil, but as the search for oil was the primary object in the drilling of these wells, the drillers paid little attention to the quality or quantity of water struck at various horizons, and the information afforded by the logs of the wells is meager.

The question of the possibility of obtaining water from deep wells for irrigation was raised by the striking of a strong flow in a well drilled for oil about half a mile east of Gage, in the SE. $\frac{1}{4}$ SW. $\frac{1}{4}$ sec. 2, T. 21 N., R. 24 W. (See Pl. IV.) The well was drilled by the Guarantee Development Co. It is 10 inches in diameter and when visited by the writer had reached a depth of 516 feet. The log of the well, from the driller's record, is given below. This log is not strictly reliable, however, for two reasons-first, the drilling was done with a rotary hydraulic rig, and it is impossible to get good samples when such a method is employed; second, a comparison of the log with samples studied by the writer shows that the presence of gypsum at several places was apparently not recognized, and there is reason to believe that material was called gypsum which was not gypsum. 
U. S. GEOLOGICAL SURVEY WATER-SUPPLY PAPER 500 PLATE IV



A. FLOWING WELL HALF A MILE EAST OF GAGE, OKLA.

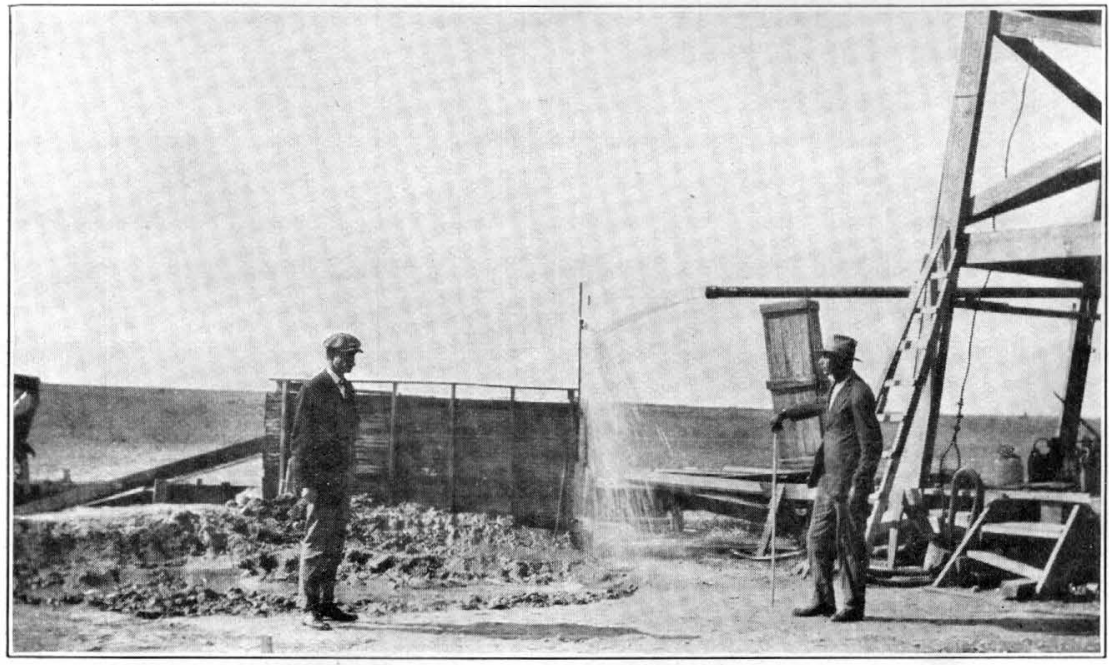

B. NEAR VIEW OF FLOWING WELL NEAR GAGE, OKLA., SHOWING DiSCHARGE. 
Record of well in the SE. $\frac{1}{4}$ SW. $\frac{1}{4}$ sec. $2, T .21$ N., R. 24 W., near Gage, Ellis County, Okla.

[Drilled June 2 to Aug. 19, 1918, by Guarantee Development Co. From driller's record sheets.]

\begin{tabular}{|c|c|c|c|c|c|}
\hline & $\begin{array}{l}\text { Thick- } \\
\text { ness. }\end{array}$ & Depth. & & $\begin{array}{c}\text { Thick- } \\
\text { ness. }\end{array}$ & Depth. \\
\hline & Feet. & Feet. & & Feet. & Feet. \\
\hline Sand ....... & 20 & 20 & Oil sand ........... & $\begin{array}{r}6 \\
12\end{array}$ & 273 \\
\hline Clay....... & $\begin{array}{r}10 \\
2\end{array}$ & $\begin{array}{l}30 \\
32\end{array}$ & $\begin{array}{l}\text { Sand and gravel. } \\
\text { Red shale........ }\end{array}$ & 13 & 298 \\
\hline Gravel & 5 & 37 & Clay and rock & 10 & 308 \\
\hline "Pack" sand.... & 4 & 41 & Sand...... & 4 & 312 \\
\hline Sanc & 7 & 48 & Sand and clay & 13 & 325 \\
\hline avel... & 10 & 58 & Sand and gravel... & 9 & 334 \\
\hline Sandrock & 33 & 91 & Sand anc shal & 11 & 345 \\
\hline Sand. & 25 & 116 & Red sand.... & 13 & 358 \\
\hline Rock and & 8 & 124 & Sand; nowa & 12 & 370 \\
\hline Rocl & 4 & 128 & Red sand. & 12 & 382 \\
\hline San & 5 & 133 & Red shale and gravel.. & 12 & 394 \\
\hline Red s & 11 & 14 & Red shal & 9 & 403 \\
\hline hd and"gyp"... & 14 & 158 & Red shale and gravel. & 13 & 416 \\
\hline rock............. & 20 & 178 & Shale and gravel........ & 9 & 425 \\
\hline "Par & 22 & 200 & Hard shale.. & 6 & 431 \\
\hline Red shale. & 14 & 214 & Red shale... & 8 & 439 \\
\hline Lime & 4 & 218 & Shale and gravel....... & 6 & 445 \\
\hline Soft $\mathrm{r}$ & 14 & 232 & Gravel and sand; some water..... & 8. & 453 \\
\hline Sand. & 3 & 235 & 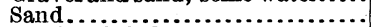 & 4 & 457 \\
\hline Sand an & 3 & 23 & Sand and shale............... & 11 & 468 \\
\hline Rock.. & 2 & 240 & Blue shale. & 5 & 473 \\
\hline Sand. & $\overline{5}$ & 245 & Red shale sand.. & 8 & 481 \\
\hline Sand and ro & 2 & 247 & Shale and gravel...... & 15 & 496 \\
\hline Sand and clay. & 2 & 249 & Red sandrock. & 12 & 508 \\
\hline ( & 9 & 258 & Gas rock, blue shale.............. & 8 & 516 \\
\hline Clay & 9 & 26 & & & \\
\hline
\end{tabular}

Samples from several different depths that were examined by the writer contained gypsum in varying quantities. Small amounts were found at 455 feet and 468 feet. A piece of rock about 4 inches in diameter that was said to have come from a depth of 508 feet contained a large percentage of gypsum. It was essentially a mass of gypsum crystals embedded in fine sand. Samples from depths of 512 and 516 feet also contained gypsum, but at these depths the gypsum may have fallen in from higher beds. The strata from which the flow of water comes apparently contain a large amount of gypsum.

Water was encountered in sandstone at 74 feet and again at 445 feet. There is no information available as to the quality or quantity of the water found at these depths. When the depth of 507 feet was reached water was struck and rose to the surface, overflowing in large volume, and drilling was suspended for a few days. When drilling was resumed and had reached a depth of 515 feet the flow increased to about four times the amount yielded at 507 feet, and it was necessary to stop drilling until some means of shutting off the water was found.

When the well was visited by the writer, in the middle of September, 1918, a 4-inch pipe had been connected to the 10-inch casing and extended vertically 70 feet or more above the surface, and a 4 -inch pipe about 16 feet long was also attached horizontally as a discharge pipe about 8 feet above the ground. A strong stream flowed from

$31219^{\circ}-22-4$ 
the horizontal pipe, and it was stated that at the same time the water stood in the vertical pipe about 60 feet from the ground, but this statement was not confirmed. Approximate measurements of the flow under these conditions, made by the writer, indicate that the flow was at least 600 gallons a minute, or more than 850,000 gallons a day.

Since the well was visited by the writer it has been drilled several hundred feet deeper, but the strong flow of the water interfered with the work. In the later drilling several large cavities were encountered. The flow increased when a large cavity was struck at 557 feet, but it decreased again to about the original flow when another cavity was encountered at 574 feet.

The water has a perceptibly salty taste. An assay of a sample in the laboratory of the water-resources branch of the Geological Survey shows that the water contains 6,200 parts per million of dissolved solids. (See assay No. 4, p. 50.) This assay shows it to be unfit for domestic and boiled use and bad for irrigation. (See pp. 48-51 for discussion of quality of water for domestic use, boilers, and irrigation.)

Large quantities of water have been struck in other deep wells within 40 miles of Gage, although so far as is known there has been no other well in which the water rose above the surface. Practically every one of these wells was being drilled for oil, and little attention was paid to the water-bearing strata, to the quantity of the water: except as it interfered with drilling, or to the quality of the water.

Two wells have been drilled on the farm of C. D. Schultz, in the NW. $\frac{1}{4}$ sec. 1 , T. 19 N., R. 25 W., about $3 \frac{1}{2}$ miles northwest of Arnett. One of the wells was drilled by the Shattuck Oil \& Gas Co. during the years 1914 to 1917 to a depth of 1,743 feet and subsequently abandoned. The "Red Beds" were apparently reached at about 165 feet. Water was encountered at 60 to 65 feet, 85 to 95 feet, 410 to 450 feet (in red sand), and 565 to 575 feet (in brown quicksand). It is possible that water was encountered at lower levels but was not mentioned in the log. When this well was visited by the writer water was standing in it only 27 feet from the surface. It was said that the well was at that time cased to 475 feet, and the water therefore presumably came from a depth greater than that. It is possible, however, that the water entered from a higher level through holes in the casing. In a shallow well a few hundred feet distant the water stands at 60 feet below the surface. This water probably comes from the same strata as were penetrated in the deep well between 60 and 65 feet. It comes from Tertiary beds, as is shown by outcrops near by. The water in the deep well probably comes from the beds at 410 to 450 feet, or 565 to 575 feet, or possibly from a greater depth.

The second deep well on the Schultz farm was being drilled by Mr. Schultz at the time of the writer's visit. The log of the well as 
obtained from the driller is obviously inaccurate. Water was reached at about 80 feet, as in the shallow well mentioned above. Water was also encountered at about 170 feet in red sandstone, and this water rose within about 100 feet of the surface. It could be bailed down about 50 feet (150 feet from the surface) but no farther. Water was also encountered at about 685 feet and at 721 feet.

It is clear that in the wells on the Schultz farm the water encountered in the "Red Beds" is under more or less artesian pressure. No samples of water were obtained from either of these two deep wells, and no definite information could be obtained in regard to the quality of the water at different depths. Salt crystals that had been precipitated from the dried sludge at the well which was being drilled indicated that the water had been rather salty, and there were similar but less pronounced indications at the abandoned well.

In a well drilled by the Home Producers Oil Co. in sec. 3, T. 21 N., R. 21 W., about 8 miles southwest of Woodward, water was encountered in quicksand between 50 and 172 feet. This water was apparently fresh and probably came from Tertiary rocks. No mention is made in the log of this well as to the quantity of water. The "Red Beds" were entered at 172 feet, and gypsum was encountered at 460 feet and at lower depths. At 852 feet salt water was encountered. The water rose within 100 feet of the top, and the inflow was so great that it could not be lowered by bailing.

In a well near Lipscomb, about 30 miles southwest of Gage, water was encountered at 430 feet and rose within 43 feet of the top. The water, which was salty, was pumped at the rate of 8 gallons a minute without being lowered. At this place the "Red Beds" were apparently entered at a depth of 92 feet.

In a well about 3 miles southwest of May, 20 miles north of Gage, salt water was encountered at 140 feet. The water rose in the well, but just how far is not known. This well was drilled to a depth of: only 150 feet.

In a well near Gate, about 40 miles northwest of Gage, water was: struck in the "Red Beds" at a depth of 170 feet and rose to the surface. Nothing is known as to the quantity or quality of the water.

In every well concerning which information was obtained where water was encountered in the "Red Beds" the water rose in the well, and in some wells it was evidently under considerable pressure. Accurate information was not available in regard to the relative elevations of the several wells, so that it is not possible to compare the head of the water at the different places. The wells on the Schultz farm are probably from 200 to 300 feet higher than the one at Gage, and the water in those wells probably stands higher than the surface 
at Gage. The Home Producers' well, southwest of Woodward, is possibly lower than the Gage well.

\section{ARTESIAN CONDITIONS IN THE " RED BEDS."}

The facts indicate that artesian conditions occur in the "Red Beds" in the Gage region, but not enough information is available to determine the structure accurately. Two possible causes of the artesian pressure may be suggested.

Near Woodward the "Red Beds" dip gently in a westerly direction. The "Red Beds" are known to continue to the west for many miles, coming to the surface in New Mexico. At points in the Panhandle of Texas and in New Mexico they are known to dip eastward. The Gage region may therefore be in a great artesian trough or syncline in which water is inclosed under pressure. The "Red Beds". at their outcrop in New Mexico are from 2,000 to 3,000 feet higher than in the Gage region. They consist of alternate beds of porous sandstone and nearly impervious shale in which are included beds of salt and gypsum. Water that falls as rain or snow on the porous beds percolates downward, along the dip of the beds, and is confined by the overlying impervious beds. The water continues to percolate downward in an easterly direction until it reaches the bottom of the basin, or until it is prevented from going farther by water that has previously accumulated. These conditions are illustrated in figure 6 (p. 38). At Gage, for instance, the flowing well is so much lower than the intake of the water-bearing bed that the pressure is great enough to raise the water 60 feet or more above the ground. On the other hand, at the Schultz wells, northwest of Arnett, the surface is much higher, and the pressure is not sufficient to lift the water to the surface.

An alternate explanation is that Gage stands on a local syncline and that the water in the "Red Beds" did not enter them at their outcrop in New Mexico, but that it entered them from the overlying porous Tertiary deposits. This condition is shown in figure 7 (p. 39).

A small-scale topographic map of Oklahoma ${ }^{3}$ indicates that all the outcrops of the "Red Beds" east of the Gage region are lower than the surface at Gage. It is therefore practically certain that the artesian water comes from the west, northwest, or southwest.

\section{QUALITY OF WATER.}

To obtain information in regard to the quality of the water in the Gage region samples were collected from the flowing well at Gage, from two shallower wells, and from Wolf Creek at Gage. These

${ }^{3}$ Gould, C. N., Geology and water resources of Oklahoma: U. S, Geol. Survey WaterSupply Paper 148, pl. 1, 1905. 
samples were assayed in the water-resources laboratory of the Geological Survey. The results of these assays, together with a classification of the waters for domestic use, boilers, and irrigation, are given on page 50.4 Because of the pressure of war work complete analyses were not made. The assays, however, are sufficiently accurate to serve as a basis for the classification of these waters as given in the table.

\section{WATER FOR DOMESTIC USE.}

The classification of the waters for domestic use given in the table on page 50 is based on the dissolved solids which they contain, especially on the constituents that produce hardness. Local conditions and individual preference largely determine the significance of the terms "good" or "bad" as applied to the mineral quality of water for domestic use. For instance, a certain water in the Gage region, where water of good quality is obtained in the Tertiary deposits, might be classed as only fair or poor, but a water of the same quality in the "Red Beds" area, where most of the water is so bad that it can not be used, would probably be classed as good. It should be borne in mind that in this report the classification of a water for domestic use is based only on its mineral composition and does not take into consideration the sanitary quality of the water.

\section{WATER FOR USE IN BOILERS.}

With respect to their quality for use in boilers, waters are classified according to the amounts of scale-forming and foaming constituents they contain and the probability of corrosion.

In this report waters for use in boilers are classed according to the rating adopted by the American Railway Engineering and Maintenance of Way Association. ${ }^{5}$

\section{WATER FOR IRRIGATION.}

Certain chemical compounds, if present in water in too large quantities, may prove harmful to vegetation. The substances most commonly encountered are what are called "the alkalies"-that is, salts of sodium and potassium. The principal harmful alkali salts are sodium carbonate (sal soda), sodium sulphate (Glauber salt), and sodium chloride (table salt).

As a result of continued evaporation much of the mineral content of the water is deposited in the soil, so that unless special precautions

\footnotetext{
- See Mendenhall, W. C., Dole, R. B., and Stabler, Herman, Ground water in San Joaquin Valley, Calif.: U. S. Geol. Survey Water-Supply Paper 398, pp. 73-82, 1916, for a detailed discussion of the classification of waters for domestic use, bollers, and irrigation.

5 Am. Ry. Eng. and Maintenance of Way Assoc. Proc., vol. 5, p. 595, 1904; vol. 9, p. 134, 1908. This classification is also given in Water-Supply Paper 398, p. 67, with the amounts of the constituents recomputed to parts per mlllion.
} 
are taken to wash out the alkali the soil will become so impregnated with the injurious substances that plants will be stunted or killed. If conditions are such that the water can drain through the soil readily, as in a very sandy soil, and not deposit much of its alkali content, the water is less likely to injure the plants than if the soil is impervious, as in clay soil, where the alkali will be deposited in the ground. The classification of the waters for irrigation as given in the subjoined table is based on the rating prepared by Stabler. ${ }^{8}$

\section{QUALITY OF WATERS IN THE GAGE REGION.}

The samples of water collected for examination represent supplies from the various types of sources in the region. The analytical results given in the following table show that the waters as a rule are fair or good for domestic use and irrigation except that from the deep well at Gage, but that they are not so good for use in boilers.

\section{Results of laboratory assays and classification of waters near Gage, Okla.}

[Parts per million except as otherwise designated; Alfred A. Chambers, C. H. Kidwell, and Margaret D. Foster, analysts.]

\begin{tabular}{|c|c|c|c|c|}
\hline & 1 & 2 & 3 & 4 \\
\hline 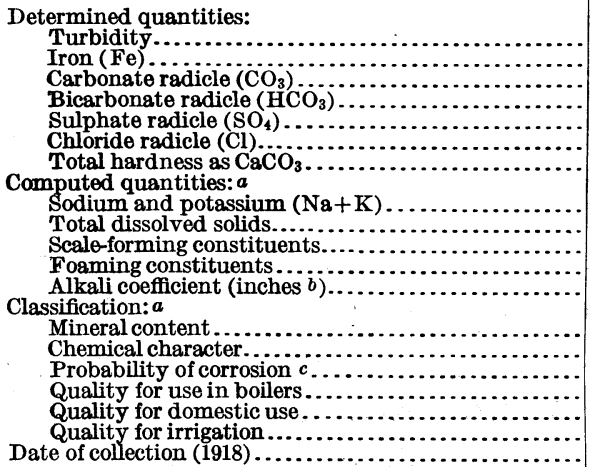 & 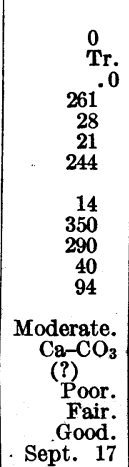 & \begin{tabular}{|c|}
15 \\
Tr. \\
4.8 \\
259 \\
34 \\
107 \\
187 \\
110 \\
480 \\
220 \\
300 \\
11 \\
Moderate. \\
Na-CO. \\
N \\
Bad. \\
Good. \\
Fair. \\
Sept. 20
\end{tabular} & $\begin{array}{c}0 \\
.17 \\
256 \\
27 \\
14 \\
207 \\
25 \\
330 \\
260 \\
70 \\
74 \\
\text { Moderate. } \\
\text { Ca-CO. } \\
\text { (?) } \\
\text { Poor. } \\
\text { Good. } \\
\text { Good. } \\
\text { Sept. } 17\end{array}$ & $\begin{array}{r}0.0 \\
83 \\
2,000 \\
1,935 \\
1,975 \\
1,500 \\
6,200 \\
2,000 \\
4,000 \\
1.0 \\
\text { Very high. } \\
\text { Na-cl. } \\
\text { C } \\
\text { Unfit. } \\
\text { Unfit. } \\
\text { Bad. } \\
\text { Sept. 20 }\end{array}$ \\
\hline
\end{tabular}

a See standards for classification by R. B. Dole and Herman Stabler, in Mendenhall, Dole, and Stabler, Ground waters in San Joaquin Valley, Calif.; U. S. Geol. Survey Water-Supply Paper 398, pp. 50-81, 1916. $b$ Depth in inches of water which would on evaporation yield sufficient alkali to render $\mathbf{a} 4$-foot depth of soil injurious to the most sensitive crops.

c Based on computed quantity; $\mathrm{C}=$ corrosive; $\mathrm{N}=$ noncorrosive; (?)=corrosion uncertain or doubtful.

1. Public supply for Gage, from driven wells 39 feet deep.

3. Wrilled well, 156 feet deep, on farm of E. J. La Lone, in the SE. 1 sec. 21 , T. 21 N., R. 24 W.

4. Flowing well, 516 feet deep, half a mile east of Gage, in the SE. $\frac{1}{\mathrm{~S} W}$. $\frac{1}{1}$ sec. 2, T. 21 N., R. 24 W., drilled by Guarantee Development Co.

Sample 1, from the driven wells that furnish the supply for the town of Gage, was taken as representative of water from the alluvial deposits along Wolf Creek. -The water is rated as only fair for

- Stabler, Herman, Some stream waters of the western United States, with chapters on sediment carried by the Rio Grande and the industrial application of water analyses: U. S. Geol. Survey Water-Supply Paper 274, pp. 177-179, 1911. . See also U. S. Geol. Survey Water-Supply Paper 398, p. 57, 1916. 
domestic use because of its hardness. It will probably require considerable soap for washing and may form a scale in kettles but is satisfactory for drinking and cooking. It has been classed as poor for use in boilers because of the amount of scale-forming constituents it contains. The water is good for irrigation.

Sample 2 was taken from Wolf Creek at the bridge a short distance north of Gage. This water has been classed as good fordomestic use; it is lower in total hardness than that from the town wells. It is, however, possibly subject to contamination, although such a condition can not be detected by the assay method. Moreover, the quality of the water in Wolf Creek probably varies with the stage of the stream. The water is classed as bad for use in boilers because of its high content of scale-forming and foaming constituents. It is of fair quality for irrigation.

Sample 3 was taken from a well on the uplands in sec. 21, T. 21 N., R. 24 W., about 3 miles south of Gage. It is believed to be representative of water obtained from wells in the Tertiary beds. It has been classed as good for drinking and general household use; poor for use in boilers because of the amount of scale-forming constituents it contains; and good for irrigation.

Sample 4, from the flowing well at Gage, is highly mineralized, containing more than 6,000 parts per million of total solids. It is unfit for either domestic use or boilers. If used for drinking it probably would produce very unpleasant if not serious effects. It can not be successfully used for irrigation. The water might possibly be used for a short period with apparent good effects, especially in a porous soil, but it would eventually deposit so much alkali that the land would be spoiled and could be brought back to productivity only by careful drainage for a considerable time. When the flow was first struck it was allowed to run through a field of broom corn near by for about two weeks. The broom corn that had been watered by the flow was noticeably in much better condition than that in the other parts of the field, which were in poor condition because of the dry weather, but a white alkali crust appeared at the surface after the flow was diverted, and undoubtedly a considerable amount of alkali was mixed in the soil beneath the surface.

\section{IRRIGATION.}

In determining the feasibility of using ground water for irrigation several factors must be taken into consideration. These are principally the quantity of water available, the quality of the water, the cost of the necessary developments, and the probable return on the investment. So far as is known there have been no attempts at irrigation in the Gage region except possibly of gardens for household use. 
The first two factors may be considered together. What information is obtained from records of deep wells in the Gage region indicates that abundant supplies of water may be obtained from the "Red Beds" at depths of 150 to 500 feet or more, but the water obtained from these beds is generally salty and can not be used for irrigation without danger of spoiling the land for crops. It is therefore concluded that water suitable for irrigation can not generally be obtained from wells that penetrate the "Red Beds." Water fit for use in irrigation may occur in some portions of the "Red Beds" that do not contain salt or gypsum, as perhaps some parts of the Woodward formation. This, however, can not be proved in the absence of wells which penetrate the upper "Red Beds" and in which careful observations as to the quality and quantity of the water obtained at various depths have been made during the progress of drilling. Any deep wells that are drilled into the "Red Beds" can only be considered as experimental until proved otherwise. The high initial cost of such wells and the hæzard of encountering bad water preclude the undertaking of the experiment by the farmer of average means.

The water obtained from wells in Tertiary deposits on the upland is of much better quality and probably is in general good for irrigation. As there is no information at hand, however, in regard to the yield of drilled wells of large diameter in this area, the possibility of obtaining water for irrigation from such wells is uncertain. The Tertiary formations probably will not yield large quantities of water for extended periods, and in some parts of the region the lift will be so great that the wells can not be pumped for irrigation. As windmills are used so generally in this region, the wind blowing steadily for long periods, it is possible to pump water for irrigation by windmills from a greater depth than would otherwise be profitable. Because the yield of such wells is only moderate it would be necessary to provide storage reservoirs, and in any event the area that could be irrigated would be small.

Computations based on the assay of the water from driven wells in the alluvium underlying the valley floor of Wolf Creek at Gage show that it is of good quality for irrigation. The quality of the water from this formation may vary somewhat from place to place, but probably everywhere in the valley of Wolf Creek it is either good or fair and can be used if reasonable care is taken in watering crops. The wells that furnish the public supply at Gage and the railroad well at Fargo yield 150 gallons a minute or more, and at these places water is obtained at depths of less than 50 feet. It is reasonable to believe that wells of similar capacity can be obtained at other places in the valley and that the water can be used for irrigation, either to supplement the rainfall in dry years or as a regular supply. The water could probably be obtained from bored wells of large diameter, 
from dug wells, or from a series of driven pipes. In addition to the water from wells on the flood plain some water could be obtained from Wolf Creek, by pumping directly from the creek or from pipes driven into the creek bed. There seems to be no possibility of storing the flow of the creek, because no good dam site is available.

In addition to the quality and quantity of the water available, the cost of the development is an important item that must be carefully considered. It is not within the scope of this paper to discuss the cost of an irrigation system in the Gage region, but attention may be called to certain points to be considered in an estimate of the cost. The original cost will include the cost of sinking wells, installing the pumping equipment, leveling the land, and building ditches. The operating expenses will include the cost of the power, of repairs, and of the distribution and application of water. In addition, the interest on the investment, depreciation, and taxes must be considered. It should be remembered that if an irrigation system is used only to supplement rainfall, the fixed charges, such as taxes, interest on investment, and depreciation, continue when the plant is idle and will therefore be relatively higher than if the plant were used regularly.

A factor of some weight in determining whether irrigation will be profitable is the nature of the crop to be raised. Because of the cost of equipment and of pumping, the ordinary field crops can not be grown by irrigation to yield as great a profit as those raised without irrigation in wet seasons, or perhaps in seasons of average rainfall. Irrigation of alfalfa and other crops grown in semiarid regions, such as broom corn, kafir corn, feterita, and Sudan grass, would probably be profitable only in dry seasons. Irrigation by water from wells is most profitable when the crops grown are those that permit intensive cultivation and that bring good prices, such as fruit and garden vegetables. In conclusion, it may be said that the prospects of obtaining water for irrigation in the Gage region are not bright, except in certain small areas. 
